\title{
Menstrual Trolls: The Collective Rhetoric of Periods for Pence
}

\author{
Berkley D. Conner
}

After two months of amending, a 37-13 Senate vote, and a 60-40 House vote in favor, on March 24, 2016, Indiana Governor Mike Pence signed House Enrolled Act 1337 into law. Authored by Indiana Representative Casey Cox and co-authored by Indiana Representatives Peggy Mayfield, Ronald Bacon, and Chris Judy, the law served to mitigate the fear that women often seek abortions after they have learned of a fetus' genetic makeup; would-be parents are either unhappy with the race or sex of the fetus; or that they worry that the future child may be born with genetic anomalies. As such, HEA 1337 sought to strengthen the severity of Indiana's existing abortion laws in three major ways: first, by prohibiting abortion on the basis of race, sex, or diagnosis of disability; second, by enhancing informed consent provisions by adding to the list of information that an abortion provider must impart to anyone seeking an abortion; and, third, by adding a requirement that the remains of any miscarriage or abortion be cremated or buried (Tuttle 2016). While the law was met with much criticism by Hoosiers, HEA 1337's measure regarding interment generated the most outrage.

Because fertilized eggs can be released and expelled during menstruation, any period could be a technical miscarriage, making menstrual fluid subject to HEA 1337s interment clause. The thought of being legally required to bury her menstrual blood compelled Carmel, Indiana, resident Laura Shanley to call Mike Pence's office to offer details about her period, feigning concern that she would be prosecuted under the new law. When asked about her call, Shanley told the Indianapolis Star, "If the governor is this interested in what's going on in my body, I might as well call and tell him" (Rudavskey 2016 , para. 2). What started as an angry phone call quickly became an organized effort to protest HEA 1337. Shanley started a Facebook page and, shortly after, a Twitter account using the moniker 'Periods for Pence,' where 
she transcribed her phone conversation and invited other Indiana menstruators to follow suit. From March 2016 through July 2016 (when Pence was announced as Donald Trump's vice-presidential running mate) the members of Periods for Pence made calls straight to Pence's office in the interest of sharing information about their individual menstrual cycles. ${ }^{1}$ Shanley transcribed these phone conversations on Facebook and Twitter for followers to read, like, and leave commentary.

While it may be easy to dismiss Periods for Pence as another instance of internet 'slacktivism,' the goal of the campaign was to mobilize menstruators to persuade lawmakers to make legislative change using their periods. The calls made on behalf of Periods for Pence are funny, sarcastic, biting, and copious, which earned the campaign national recognition. Cosmopolitan reported that in April 2016, Pence's office was forced to shut down their phone lines because it was receiving so many calls about periods (Gupta 2016), New York Magazine claimed that Periods for Pence's brand of "menstrual trolling" was "the best new kind of trolling" (Rinkunas 2016, para. 5), and Triple Pundit argued the campaign was "the perfect example of spurring change at the policy level" (Mazzoni 2016, para. 6). To date, the campaign's Facebook page boasts nearly 100,000 'likes' while the Twitter account is followed by nearly 6500 users.

Because it is such a variable phenomenon, mobilizing around menstruation is difficult (Weiss-Wolf 2017, xviii-xix). However, in this chapter, I explore how the activists of Periods for Pence relied on diverse experiences with menstruation to protest anti-abortion legislation. Using Tasha N. Dubriwny's (2005) theory of collective rhetoric, I argue that the activists of Periods for Pence engage in acts of narrative sharing, humor, and symbolic reversal to: (1) craft a cohesive narrative of the many experiences of menstruation, and (2) draw on logics of menstruation to rhetorically re-moralize abortion as necessary. Finally, I will demonstrate that Periods for Pence successfully employs a second-wave feminist strategy, consciousness-raising, in a third-wave feminist context. Thus, I also draw on Chris Bobel's notion of radical menstruation $(2010,110)$ to argue that Periods for Pence can help scholars rethink traditional conceptualizations of static 'waves' of feminism and feminist rhetorical theorizing.

I examine the Periods for Pence Facebook page and Twitter account between the dates of March 28, 2016 (the day the accounts were created) and April 21, 2016, the day of the Rally for Women's Rights at the Indiana Statehouse. The posts between these dates are most consistently transcriptions of phone calls made to Pence's office. After the rally, the accounts mainly became used for sharing news articles related to Pence and reproductive health. I analyze 20 Facebook and Twitter posts, comments, and replies from 19 different rhetors that best represent the discourse of Periods for Pence. These posts are created by people participating in the campaign, including Laura Shanley, either as callers or supporters seeking advice about making calls. 


\section{Menstruation, Feminism, and Activism}

Feminist thinkers in sociology, anthropology, and women's studies have taken up the question of menstruating bodies largely by contributing to research about the Western, cultural menstrual taboo. This foundational work importantly links the taboo to a history of systemic sexism that identifies bodily fluid as both feminine and dirty. Elizabeth Grosz (1994) argues that, centuries ago, bodily fluids came to be indicative of physiological and social differences between men and women. ${ }^{2}$ Marking the woman's body as "a body which leaks, which bleeds, which is at the mercy of hormonal and reproductive functions" (Grosz 1994, 204) allows for easier subjugation of both the blood and of the person who bleeds. Indeed, menstrual blood and its bleeders are given meaning based on the ideals of male, heterosexual desire. In other words, menstrual blood is dirty and so are menstruating women. Mary Douglas (2002) asserts that this point of view birthed the menstruation taboo, which persists because of society's association of menstrual blood with a bodily type of pollution. Often, the notion of pollution is mobilized against menstruators to justify policing the menstruating body. Janet Lee and Jennifer Sasser-Coen (1996) explain that once a woman feels shame related to the dirtiness of her body, a symbolic resemblance exists between the limits of the body and danger to the community, freeing society to intervene and manage the body for the good of the community. In this way, sexism becomes a public safety measure.

Centralizing menstruation in conversations about sexism and taboo opened doors for rhetorical scholars to pay closer attention to how taboo materializes as marginalizing legislation. Although rhetorical conversations do not typically focus on menstrual blood, rhetorical literature has focused on blood in various contexts, cementing the necessity of understanding blood discourse. For example, some rhetorical blood scholarship interrogates questions of biopolitics that are often linked to toxicity. Jeffrey Bennett (2015) argues that the FDA's ban of blood donations from gay men is couched in a rhetoric of contagion that bolsters the political and social othering of these men. For women, toxicity extends beyond menstrual blood to often include reproductive organs writ large. Mollie Murphy (2017), in her exploration of the link between reproductive and environmental justice, contends that the toxicity of the womb is highly stigmatized and isolated to the private sphere where medical issues related to childbirth and abortion are less likely to be acknowledged. While these scholars highlight the importance and materiality of social constructions of blood, others are interested in how bleeders utilize these negative constructions in order to recast blood in a positive way. Elizabeth Dickinson, Karen Foss, and Charlotte Kroløkke (2017) explore postpartum placenta consumption and burial and reveal that these placenta practices operate rhetorically within logics of disgust. Specifically, mothers who engage in placenta practices rearticulate what 'disgust' means in the context of Western medicine in order to reshape public perception of placenta 
practices. Importantly, rhetoricians who study blood are interested not only in how certain blood becomes weaponized against its bleeders, but also how these bleeders may disrupt this process.

Rhetorical work that does engage menstruation often focuses on how menstrual blood is policed through the deployment of lifestyle feminism. This typically happens at the corporate level in service of capitalism. Elizabeth Kissling (2013) and Carly Woods (2013) have both explored how oral contraceptives are marketed to highlight their potential as menstrual suppressors. This decision is often made in the name of postfeminism or choice feminism; pharmaceutical companies capitalize on the menstruation taboo in order to sell the idea that women are happier, healthier, and more able when they are free of their periods. Woods contends that these advertisements succeed in marketing an illusion of 'choice' that offers women a false sense of control over their bodies and lives, while, at the same time, reinstating ideologies of the patriarchy. For both Kissling and Woods, menstruation is an important battleground on which feminists are sparring over matters of agency.

While multidisciplinary feminist thought and rhetorical scholarship engaging menstruation and blood are critical to understanding how humans have come to know menstruation, putting these fields in conversation with each other offers academics interesting ways to think through menstruation's current political moment. Performance studies scholar Shauna MacDonald (2007) models an avenue through which to link interdisciplinary feminist work that traces the lineage of menstrual oppression, and rhetorical scholarship that considers how blood is rhetorically constructed. MacDonald thinks about bodily fluids, specifically menstrual blood, as existing in a liminal space when they have exited the body. In a liminal space, matter is not subject to social structures - it is, if only temporarily, unknowable. Fluids such as menstrual blood may be engendered to the feminine, but an important characteristic of fluid is that it is able to dissolve dichotomous boundaries by literally seeping through them. This notion of liminality suggests rhetorical critics could consider how (and what is at stake when) menstrual blood is deployed by bleeders. If it is true that society has come to know menstruators as dirty, unruly, incapable, and subordinate, MacDonald suggests that the mere sight of blood via a leak (or possibly even an intentional act such as free-bleeding) puts the power of social construction back into the hands of the bleeder because fluid has effectively transcended the bounded control of the body. Because menstruation is a deeply individual experience, in order for menstrual blood to be deployed in the interest of large-scale social movements, a cooperative discourse of menstruation must be able to form. In the following section, I offer a methodological strategy that can help scholars interested in menstrual blood's liminality think about the potential of menstrual blood in the arena of activism. 


\section{A Collective Understanding of Menstruation}

I believe MacDonald's (2007) understanding of the liminality of menstrual blood has the potential to shape how scholars might think about menstruation and activism, but at the same time I recognize Weiss-Wolf's (2017) concern that it is hard to unify around issues of menstruation because every experience with menstruation is unique. As a solution, I offer that Tasha Dubriwny's (2005) theory of collective rhetoric may be a fruitful way to understand how menstrual blood becomes collectively understood and mobilized by menstruators, even when their individual experiences with menstruation are drastically different.

Dubriwny (2005) analyzes how Redstockings, a second-wave radical feminist collective, employed consciousness-raising as a means of collectively reframing public opinion about abortion in 1969. Her theory details the way "collective rhetoric emerges through strategies that enable the collaborative creation and validation of worldviews through the articulation, or the strategic linking, of individual experiences" (396). As these individual experiences amass, oppressed groups are able to create new meaning from the articulation and validation of shared, lived experiences through three rhetorical processes: personal narrative, use of humor, and symbolic reversal. Burke (1984) refers to this overall process as perspective by incongruity, and Dubriwny argues that feminist rhetoricians (Demo 2000; Foss 1979) have adopted Burke's strategy for their own purposes. What Burke calls "perspective by incongruity," Dubriwny terms "atom cracking," or the "strategic juxtaposition of incongruent ideals, values, practices, and symbols that not only call into question gender ideologies but also re-moralize them" (398). For Dubriwny, atom cracking is the ultimate goal of collective rhetoric because once an ideology is re-moralized, oppressed groups develop solidarity, which can bring about change on social and political levels.

\section{Mobilizing Around Menstruation}

Because a theory of collective rhetoric privileges how individual narratives come together to form a cohesive narrative in service of larger political goals, I see the theory as being useful for attuning to how individual narratives about menstruation can coalesce for activist purposes. Thus, using collective rhetoric as my theoretical framework, in this section I analyze the Periods for Pence posts to illuminate how the members of the campaign unified around the invocation of menstruation to protest anti-abortion legislation and sensibilities. ${ }^{3}$ The activists do this by creating a shared narrative of menstruation, using humor, and employing symbolic reversal. Their activism, I argue, re-moralizes abortion by couching the conversation in logics of menstrual health. 


\section{Sharing a Shedding Narrative}

Initially, and perhaps most importantly, Periods for Pence is built on a network of activists who share two important characteristics: they menstruate and they demand the right to have an abortion. Inevitably, then, the campaign provides these activists with a cause they can rally around and a platform on which they can support each other. Dubriwny (2005) argues that engaging in co-construction of narratives by sharing stories that build on one another helps "create a community by allowing participants to affirm and validate each other's experiences by sharing parts of their own experiences" (p. 405). In the case of Periods for Pence, shared narrative is most typically seen in the form of comments to original Periods for Pence posts in which members engage with material from the original post and proceed to share their similar experiences. In this tweet thread, several members share both their experiences with menstruation as well as their concerns about their menstrual cycles in light of HEA 1337:

@PeriodsforPols: Contact @GovPenceIN to report your periods in response to HEAl337! Because it IS his business, now! (March 30, 2016)

|@PriestessofAres: @periodsforpence @GovPenceIN Ah yes ... Would he like to know in gory detail what every girl goes through? Graphic detail? (March 30, 2016)

|@danapokie: @PriestessOfAres @periodsforpence @GovPenceIN Some symptoms of pre menopause are quite fascinating. Soaked thru 5 Playtex Ultras in $1 \mathrm{hr}$ ! (March 30, 2016)

@SpoolandThimble: @periodsforpence @GovPenceIN if I remove my tampon \& there's a big clot, should I have that interred? What if I'm in a med facility restroom? (March 30, 2016)

@ma2therisa: @periodsforpence @GovPenceIN I'm PMS'ing this week, just thought that you'd like to know. I'll be tweeting you again next week. (March 30, 2016)

The narrative becomes even more colorful when posters use vivid detail to describe what it feels and looks like to be a menstruating person. These three separate posts from Facebook and Twitter highlight the aesthetic of periods in a way that builds on the narrative from the examples above:

Periods for Pence: Me: My period is three days late, but I'm starting to get the white mucus discharge. I thought the gov should know since his hand is in my uterus.

Man: Ummm, please *stifles giggles* contact your physician. (April 11, 2016)

@kaedlen: @periodsforpence @GovPenceIN Started my PERIOD 3 days early over here in HK ... Should I worry Gov? OMGS THERE'S SO MUCH BLOOD! (April 7, 2016) 
@LoopsOFury: @periodsforpence @GovPenceIN It happened in the middle of a doozy of a period-8 days! I could feel it sort of ... slither out. (April 5, 2016)

In these examples, several different posters construct a narrative of menstruation's complications. Their tweets build off of each other until users can see a complete story detailing multiple experiences with menstruation. From symptoms to menstrual product economy to the feeling of blood slithering out of the body, these menstruators craft a vision of living as a menstruator.

What is interesting about narrative sharing in Periods for Pence is that the social media platform makes it possible for these members to create a cohesive narrative not only about their menstrual cycles, but about their involvement in the campaign. Laura Shanley tells Cosmopolitan that once she started transcribing her calls on the campaign's Facebook page, "people just started calling as well" (Gupta 2016, para. 6). Writing the content of the calls on a public platform allows the group's mission to be visibly supported and reproduced via social media functions such as liking, commenting, replying, sharing, and retweeting. Often, Periods for Pence supporters will see an original post and then either voice their desire to join in, or simply join in right away. For example:

Periods for Pence: Me: Good morning. I just wanted to call and let the good Governor know that I am still not pregnant, since he seems to be so worried about women's reproductive rights.

Irritated lady on the other end of the phone: And can I get your name, please?

Me: Sure, it's Not Pregnant Laura. (March 29, 2016)

Anjali Mirmira: My latest call:

Me: hello, I was wondering if you could tell me where Gov. Pence went to medical school?

Rep: Excuse me? He's hasn't from what I am aware of

Me: Then why does he feel like he can be the healthcare provider of every woman in Indiana and know nothing about women's healthcare?

Rep: Ma'am, do you have a constructive question? Because we've been getting these calls too often

Me: Sure. Where's the closest planned parenthood from Zionsville?

Rep: *hangs up. ${ }^{*}$ (March 29, 2016)

|Shawn Fisher: Wow! I wonder if Gov. Pence considers my tubal ligation and years later hysterectomy to be bad choices? Perhaps I should call? Thoughts? *hmmm. * (March 29, 2016)

Carl Lampman: Call and ask. (March 29, 2016)

Kathy Marquis Waugh: Please someone post his number I so want to call, thank you. (March 29, 2016) 
In this Facebook comment thread, members of Periods for Pence see the original post reflecting a phone call made by Shanley and proceed to describe their own phone calls, ask if they should call regarding certain issues related to their own cycles, voice their individual interest in participating, and support the activists in the campaign. In this way, the campaign functions to also foster a cohesive narrative about activism. The generative meaning that is produced and reproduced fosters a doors-open policy with regard to discussing personal anatomy and physiology, but also casts a wider net of interest in the campaign's cause.

Dubriwny's conception of shared narrative exists in the Periods for Pence campaign in that the commenters and responders collectively build a community that supports and solidifies the group's intentions, messages, and experiences. The activists discuss bleed-throughs, clots, and general issues with their menses-building up a narrative of the complications that arise from a bodily function they cannot easily control. At the same time, the group builds cohesion around their experiences calling Pence's office.

\section{Bloody Hilavious}

What is so appealing about Periods for Pence, even for those who would not typically enjoy casual conversation about menstrual blood, is the hilarity with which the members describe their menses. In fact, Gupta (2016) praises the campaign as being perhaps the most hilarious way to contact your representatives. Dubriwny (2005) argues that the use of humor in feminist protest, particularly when considering it through the lens of collective rhetoric, is strategic and essential. She mentions that the type of humor used for consciousness-raising centers on self-denigration and common understanding; it often speaks to the larger narrative of women's struggles to achieve bodily autonomy. Dubriwny's understanding of humor speaks to Kalcik's (1975) valuation of humor as a strategic rhetorical tool. She argues that strategic humor often initially appears to be devaluing the individual who employs its use, typically through plays on stereotypes. What makes humor based on stereotype so effective in protest is that it usually carries implicit critiques of the stereotypes it appears to propagate. For example, Dubriwny explains that Redstockings activists relied on humor that made them appear as if they did not know anything about their bodies. In reality, having knowledge about their bodies (as opposed to the men who were legislating them), was crucial to the success of the women's rights movement. To make themselves appear as if they had no knowledge of their own bodies, then, worked to reveal the dangers of not knowing about women's bodies. Content generated by the members of Periods for Pence mostly serves to humorously point out the logical flaws of HEA 1337 by highlighting the body. For example, Twitter user @lynneebrown highlights the shallow logic used in the crafting of HEA 1337 by noting that it fails to account for menstruators who have had surgical procedures and menstruators who may not biologically reproduce: 
@periodsforpence @GovPenceIN I've heard you're interested in women's reproductive health. FYI I've had a hysterectomy. Plus lesbian. (April 1, 2016)

Facebook user Rick Matlock plays on the stereotype of menstruating people as cranky and needing comfort as a way to feign interest in reporting his wife's reproductive health to Pence and inquiring about the extent to which Pence would remain financially interested in all facets of menstruators' reproductive healthcare:

My wife seems to be doing fine, just thought I would check in since the State has taken the time to be concerned with her. . . Her irritability level was 8 . Her chocolate intake level was 9 . Her snippy comments were a level 10 . . Just contact me if you need more info . . Thank You for your concern . . . BTW, do you reimburse for OB/GYN visits? Do you cover the parking garage fees as well? (April 6, 2016)

Pence's failure to understand the intricacies of the lack of menstrual blood present in a menstruator's biology is also frequently used for comedic effect. An anonymous contributor writes:

I'm 60 and stopped having my periods 10 years ago. Will I be fined for such activity? (April 6, 2016)

Another anonymous Facebook contributor feigns concern about faux medical issues to highlight Pence's lack of foresight in signing HEA 1337, as well as to call attention to Pence's history of marginalizing minority citizens:

So I knew a girl 30 years ago who had an abortion. Do you think Pence would want me to stone her the next time I see her? And since I'm gay, should I also stone myself afterwards? So many questions and not enough answers. (April 2, 2016)

While each example may not be laugh-out-loud funny, the brilliance of Periods for Pence's humor lies in the work it assigns to its audience. Chvasta (2006) argues that an enthymematic strategy such as the one employed by the Periods for Pence activists highlighted above allows audience members to find value in the protestors' cause for themselves, which increases the overall efficacy of the movement. Essentially, this strategy saves Periods for Pence protestors the burden of arguing with those who cannot and will not support their cause. Rather, their efforts are focused on those members of the audience who can see the humor in the logical gaps they have created and understand that those gaps are indicative of more serious problems embedded in the law itself as well as the law's inevitable repercussions. 


\section{A Reversal in Red}

In order for Periods for Pence to have any sort of political practicality, the campaign needed to convince their audience to believe in the serious dangers of HEA 1337. By engaging in both the spinning of cohesive narratives about reproductive health issues and the formation of enthymematic humor, the members of Periods for Pence position themselves closer to establishing an overall support system for their ideology. Before political success can be achieved, however, Dubriwny (2005) argues that its members must re-moralize abortion for their audience. In other words, Periods for Pence must convince their audience that abortion is not only a necessity but a right. The campaign attempts this by engaging in what Dubriwny calls symbolic reversal, or the re-moralizing of a contentious ideology. Regarding Periods for Pence, efforts to enact symbolic reversal are targeted toward the linking of menstruation and abortion. The campaign's argument hinges on juxtaposing the unpredictability of menstruation, as well as a myriad of logical flaws, with compliance to HEA 1337. For example:

@Sasha827: @GovPenceIN @periodsforpence Started my cycle today. When will you be by to check my used pads for HEAl337 compliance so I know to be home? (April 5, 2016)

As HEA 1337 suggests, any menstrual expulsion is subject to its jurisdiction. The goal of Periods for Pence, then, is to reject this notion. To do so is to acknowledge the link between menstruation and pregnancy. Periods for Pence does this using several techniques, all of which are humorous, and all of which indicate that regulation of the fetus inevitably involves the regulation of the menstrual cycle-a near impossible feat given menstruation's irregularity. For example, one of Laura Shanley's early calls to Pence's office is simply a report that she could not be pregnant given that her period had come and gone. This particular call highlights the impracticality of claiming to be concerned with women's reproductive health without understanding that pregnancy and menstruation are linked:

\footnotetext{
Them: Good Morning, Governor Pence's office

Me: Good Morning. I just wanted to inform the Governor that things seem to be drying up today. No babies seem to be up in there. Okay?

Them: (Sounding strangely horrified and chipper at the same time) Ma'am, can we have your name?

Me: Sure. It's Sue.

Them: And your last name?

Me: Magina. That's M-A-G-I-N-A. It rhymes with -

Them: I've got it. (March 31, 2016)
}

In a follow-up call, Shanley details just how easily a pregnancy can go wrong against a mother's wishes, often resulting in expelled blood: 
Me: Hello, this is Sue Magina again. I just hit a pothole on I-70. It was a doozy! I'm worried it might have shaken something around up in there, and I wanted to make sure that was addressed in this new abortion law. I knew Governor Pence would be worried. Thanks. (April 1, 2016)

And perhaps the best example to demonstrate Periods for Pence's use of symbolic reversal is Shanley's very first phone call to Pence's office, used as a previous example as well. She lets the staff know that she still is not pregnant (likely due to the arrival of her period), and effectively translates the entire point of Periods for Pence:

Me: Good morning. I just wanted to call and let the good Governor know that I am still not pregnant, since he seems to be so worried about women's reproductive rights.

Irritated lady on the other end of the phone: And can I get your name, please?

Me: Sure, it's Not Pregnant Laura. (March 29, 2016)

While Periods for Pence does support the notion that abortion is a moral, legal right, the campaign, as exemplified above, mostly concerns itself with circumstances in which a terminated pregnancy lies outside a menstruator's impetus of control. In Periods for Pence's eyes, HEA 1337 is Mike Pence's way of criminalizing abortions that were had via informed decision making, but the law also punishes those who did not make a choice to terminate a pregnancy. In order to convince those with political power that the law is not sound enough to remain, Periods for Pence had to get their audience to understand that HEA 1337 had ramifications beyond those that Mike Pence sought to implement.

\section{On Feminism, Fluids, and Fluidity}

The explicit detail with which the activists of Periods for Pence protest HEA 1337 spins a singular narrative of menstruation while celebrating differences in the phenomenon. In the interest of this campaign, talking about menstruation diminishes the boundaries that varied experiences with periods might build between menstruators. Through their posts, menstruation is cast as complicated, dangerous, funny, annoying, painful, messy, and even banal. The support for these experiences by other members of group indicate that menstruation can, overall, be thought of as unpredictable and part of living. Importantly, this is how Periods for Pence rhetorically links menstruation discourse with abortion discourse. In much the same way that menstruation is unable to be controlled, the circumstances of pregnancy, and often, the termination of that pregnancy, are unable to be controlled.

If it is true that bodily fluid can dissolve boundaries, we might think about how menstrual blood is implicated in this notion. What differences exist between different displays of menstrual blood in protest? Is an accidental 
menstrual leak different from a purposeful display of menstrual blood? If so, how? Can menstrual fluid dissolve racial boundaries? How can we theorize the menstruating bodies of people who are transgender or gender non-binary? ${ }^{4}$ These questions can be answered if rhetorical scholars pay attention to how blood is deployed by bleeders. Periods for Pence helps us start to think about this because even though no actual blood is used, it is absolutely invoked in great detail. What is the performative potential of talking about menstrual blood? This case study suggests that deploying Kissling's (1996) notion of the communication taboo for political purposes is useful. In the wake of Periods for Pence, Planned Parenthood of Indiana and Kentucky planned to request a preliminary injunction to block Pence's restrictions. In June of 2016, U.S. District Court judge Tanya Walton Pratt granted Planned Parenthood of Indiana and Kentucky's injunction, writing that HEA 1337 "directly [contravenes] the principle established in Roe v. Wade" (Pratt 2016, 2). In accordance with the injunction, HEA 1337 has not yet taken effect, although Indiana state attorneys remain open to filing an appeal. If Periods for Pence demonstrates anything, it is that scholars can and should turn their attention to bleeding (whether physically or verbally) and its potential to create policy change.

Historically, academics, public intellectuals, and activists alike have, likely for organizational purposes, distinguished between waves of feminism. But, analysis of Periods for Pence reveals that it is plausible that acts of protest in the name of feminism may not fall neatly into one wave or another. Rather, the work of the members of Periods for Pence illustrates that feminist activism has always been, and remains, fluid. Rights to reproductive health care and services remain under constant threat. As my analysis demonstrates, the same strategies used to advocate for abortion rights in 1969 are being used to advocate for abortion rights in 2017. Consciousness-raising, collective rhetoric, and embodiment strategies span decades. The strategies are not new, they are just being carried out in new ways. Periods for Pence highlights the craftiness of activists; they find ways to use the same strategies in spaces that are popular in the current time.

As such, I suggest that feminist thinkers should embrace the fluidity of feminism. Chris Bobel (2010) urges feminist scholars to continue to do work that aids feminism in delicately acknowledging its past while crafting its future. Rhetorical attention paid to menstrual blood can help feminist scholars trace a lineage of the use of blood to advocate for feminism. Where has our blood been, and where is it going? If Mike Pence learned anything during his tenure as Indiana Governor, it is that his phone lines were not prepared for a state full of menstruating people scorned. As he and likeminded politicians serve Americans from the White House at least until 2021, it is certain that the future is red. Perhaps only time will tell if blood will be shed in effect. 


\section{Notes}

1. I will refer to those who participate in Periods for Pence activism as either 'members,' 'activists,' or 'posters' since I cannot be certain of their pronouns or gender identities.

2. Much of this work refers to menstruating people as 'women' and 'females.' While I understand that this choice is essentializing, I will include the language these scholars use in order to trace the lineage of this scholarship.

3. I will typically indicate who made each post by prefacing the content with the poster's name or Twitter handle in a fashion similar to dialogue in a script. Vertical lines indicate a post was made in response to the post above it. When Pence became Trump's vice-presidential running mate, the name of the campaign was changed from Periods for Pence to Periods for Politicians, and as such the tweets from this account are indicated by @PeriodsforPols. All typos present appear in the original posts.

4. See SE Frank and Jac Dellaria, Chapter 7, Miren Guilló-Arakistain, Chapter 63, and Klara Rydström, Chapter 68, for discussion of these questions.

\section{REFERENCES}

Bennett, Jeffrey A. 2015. Banning Queer Blood: Rhetorics of Citizenship, Contagion, and Resistance. Tuscaloosa: University of Alabama Press.

Bobel, Chris. 2010. New Blood: Third-Wave Feminism and the Politics of Menstruation. New Brunswick, NJ: Rutgers University Press.

Burke, Kenneth. 1984. Permanence and Change: An Anatomy of Purpose. 3rd ed., With a new afterword. Berkeley: University of California Press.

Chvasta, Marcyrose. 2006. "Anger, Irony, and Protest: Confronting the Issue of Efficacy, Again." Text \& Performance Quarterly 26 (1): 5-16. https://doi. org/10.1080/10462930500382278.

Demo, Anne Teresa. 2000. “'The Guerilla Girl's Comic Politics of Subversion.'” Women \& Language 23 (2): 63.

Dickinson, Elizabeth, Karen Foss, and Charlotte Kroløkke. 2017. "Empowering Disgust: Redefining Alternative Postpartum Placenta Practices." Women's Studies in Communication 40 (1): 111-28. https://doi.org/10.1080/07491409.2016.124 7400 .

Douglas, Mary. 2002. Purity and Danger: An Analysis of Concept of Pollution and Taboo. Routledge Classics. London and New York: Routledge.

Dubriwny, Tasha N. 2005. "Consciousness-Raising as Collective Rhetoric: The Articulation of Experience in the Redstockings' Abortion Speak-Out of 1969.” Quarterly Journal of Speech 91 (4): 395-422.

Foss, Sonja K. 1979. "Feminism Confront Catholicism: A Study of the Use of Perspective by Incongruity." Bulletin: Women's Studies in Communication 3 (1): $7-15$.

Grosz, E. A. 1994. Volatile Bodies: Toward a Corporeal Feminism. Theories of Representation and Difference. Bloomington: Indiana University Press.

Gupta, Prachi. 2016. "Why a Woman Called Mike Pence's Office Every Day to Talk about Her Period." Cosmopolitan, November 2, 2016. http://www.cosmopolitan. $\mathrm{com} /$ politics/a8061278/periods-for-pence-sue-magina/. 
Kalcik, Susan. 1975. ““... Like Ann’s Gynecologist or the Time I Was Almost Raped’: Personal Narratives in Women's Rap Groups." The Journal of American Folklore 88 (347): 3-11. https://doi.org/10.2307/539181.

Kissling, Elizabeth Arveda. 1996. “That's Just a Basic Teen-Age Rule': Girls' Linguistic Strategies for Managing the Menstrual Communication Taboo." Journal of Applied Communication Research 24 (4): 292-309.

—. 2013. "Pills, Periods, and Postfeminism." Feminist Media Studies 13 (3): 490-504. https://doi.org/10.1080/14680777.2012.712373.

Lee, Janet, and Jennifer Sasser-Coen. 1996. Blood Stories: Menarche and the Politics of the Female Body in Contemporary U.S. Society. New York: Routledge.

MacDonald, Shauna M. 2007. "Leaky Performances: The Transformative Potential of Menstrual Leaks." Women's Studies in Communication 30 (3): 340-57.

Mazzoni, Mary. 2016. "'Periods for Pence' Is Social Media Gold." Triple Pundit, April 15, 2016. http://www.triplepundit.com/2016/04/periods-for-pence-socialmedia-gold/.

Murphy, Mollie K. 2017. "What's in the World Is in the Womb: Converging Environmental and Reproductive Justice through Synecdoche." Women's Studies in Communication 40 (2): 155-171.

Periods for Politicians/Periods for Pence. Periods for Politicians/Periods for Pence [Facebook Post]. March 29, 2016. https://www.facebook.com/REALP4P/.

Periods for Pols [PeriodsforPols]. Periods for Pols [Tweets]. March 30, 2016. https:// twitter.com/periodsforpols?lang=en.

Periods for Politicians/Periods for Pence. Periods for Politicians/Periods for Pence [Facebook Post]. March 31, 2016. https://www.facebook.com/REALP4P.

Periods for Politicians/Periods for Pence. Periods for Politicians/Periods for Pence [Facebook Post]. April 1, 2016. https://www.facebook.com/REALP4P.

Periods for Politicians/Periods for Pence. Periods for Politicians/Periods for Pence [Facebook Post]. April 2, 2016. https://www.facebook.com/REALP4P.

Periods for Politicians/Periods for Pence. Periods for Politicians/Periods for Pence [Facebook Post]. April 6, 2016. https://www.facebook.com/REALP4P.

Periods for Politicians/Periods for Pence. Periods for Politicians/Periods for Pence [Facebook Post]. April 11, 2016. https://www.facebook.com/REALP4P/.

Pratt, Tonya Walton. 2016. "Planned Parenthood of Indiana and Kentucky, INC., Dr. Marshall Levine, M.D. v. Commissioner, Indiana State Department of Health in his official capacity, et al.

Rinkunas, Susan. 2016. "Indiana Women Are Calling the Governor about Their Periods." The Cut, April 1, 2016. https://www.thecut.com/2016/04/indianawomen-calling-governor-mike-pence-about-their-periods.html.

Rudavskey, Shari. 2016. "Carmel Mom Is the Previously Unidentified Woman behind Periods for Pence." Indianapolis Star, November 2, 2016. https://www.indystar. com/story/news/2016/11/02/woman-behind-periods-pence/93186838/.

Tuttle, Ian. 2016. "Mike Pence Abortion Law Should Be Taken Seriously." National Review, April 8, 2016. http://www.nationalreview.com/article/433879/mike-penceabortion-law-should-be-taken-seriously.

Weiss-Wolf, Jennifer. 2017. Periods Gone Public: Making a Stand for Menstrual Equity. New York: Arcade Publishing.

Woods, Carly S. 2013. "Repunctuated Feminism: Marketing Menstrual Suppression Through the Rhetoric of Choice." Women's Studies in Communication 36 (3): 267-87. https://doi.org/10.1080/07491409.2013.829791. 
Open Access This chapter is licensed under the terms of the Creative Commons Attribution 4.0 International License (http://creativecommons.org/licenses/ by/4.0/), which permits use, sharing, adaptation, distribution and reproduction in any medium or format, as long as you give appropriate credit to the original author(s) and the source, provide a link to the Creative Commons license and indicate if changes were made.

The images or other third party material in this chapter are included in the chapter's Creative Commons license, unless indicated otherwise in a credit line to the material. If material is not included in the chapter's Creative Commons license and your intended use is not permitted by statutory regulation or exceeds the permitted use, you will need to obtain permission directly from the copyright holder. 